\title{
CHRONOMETR (1): ROZMOWNY BUDZIK
}

JAN ZIELIŃSKI

Wydział Nauk Humanistycznych Uniwersytetu Kardynała Stefana Wyszyńskiego; Faculty of Humanities Cardinal Stefan Wyszyński University in Warsaw (Poland) zielinski@gmx.ch
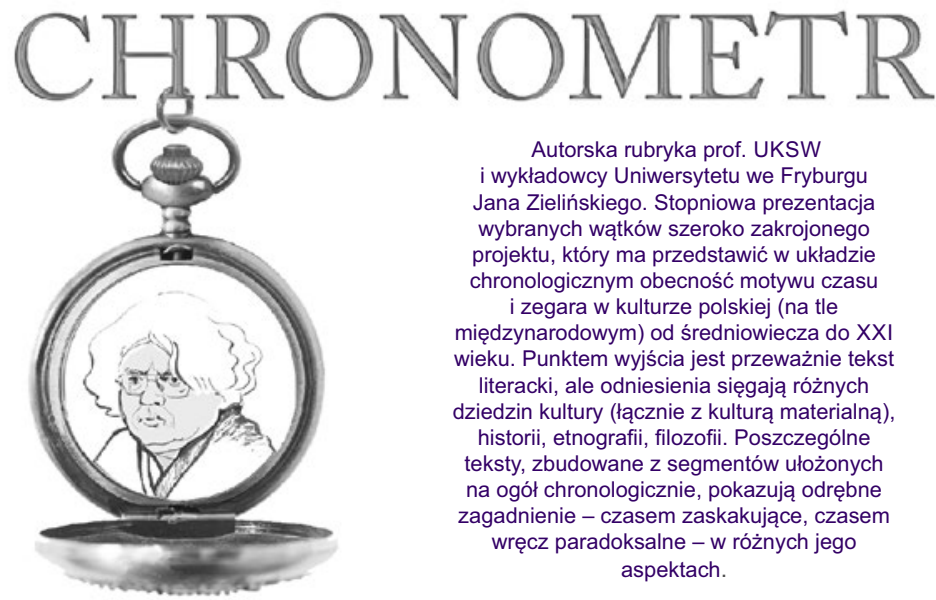

Autorska rubryka prof. UKSW i wykładowcy Uniwersytetu we Fryburgu Jana Zielińskiego. Stopniowa prezentacja wybranych wątków szeroko zakrojonego projektu, który ma przedstawić w układzie chronologicznym obecność motywu czasu i zegara w kulturze polskiej (na tle międzynarodowym) od średniowiecza do XXI wieku. Punktem wyjścia jest przeważnie tekst literacki, ale odniesienia sięgają różnych dziedzin kultury (łącznie z kulturą materialną), historii, etnografii, filozofii. Poszczególne teksty, zbudowane z segmentów ułożonych na ogół chronologicznie, pokazują odrębne zagadnienie - czasem zaskakujące, czasem wręcz paradoksalne - w różnych jego aspektach.

Wyrafinowane sposoby użycia budzika w charakterze telefonu bądź telegrafu stosowali przed I wojną światową nieuczciwi pośrednicy, czynni przy werbowaniu galicyjskich chłopów na emigrację do Ameryki. Przykłady podaje znawca tej problematyki, lwowski ekonomista Leopold Caro: 
'Dyrektor okrętu', Abraham Izaak Landerer, nakręcał budzik i w ten sposób zapytywał w Hamburgu, czy jeszcze jest miejsce na okręcie. Po jakiejś chwili znowu budzik nakręcano i przyjmowano odpowiedź. Za to porozumienie, funkcjonujące o wiele szybciej niż drut telegraficzny, pobierano osobno tylko 4-6 zł. Za pośrednictwem budzika zapytywano i w Ameryce, czy są jeszcze grunta wolne dla wychodźcy. Wreszcie szło tą samą drogą zapytanie i do 'cesarza amerykańskiego', od którego zależała ostateczna decyzja, czy chce przyjąć nowych poddanych ${ }^{1}$.

Zacytowana opowieść o budzikach ukazała się drukiem w tym samym brzmieniu w artykule Ruch wychodźczy w szponach żydowskich, zamieszczonym anonimowo 9 X 1908 roku w poznańskim „Postępie” jako przedruk z krakowskiego „Postępu”. Z książki Leopolda Caro zaczerpnie ją autor podpisany (henry) w poznańskim „Orędowniku” z 12 XII 1936 w artykule Jak hieny żydowskie żerowaty na polskich emigrantach, który dotyczy procesu filii agencji „Hapag” w Oświęcimiu, toczącego się przed sądem austriackim w Wadowicach przez blisko rok (podano: 1899-1900, w rzeczywistości było to dziesięć lat wcześniej). Jeden z podtytułów artykułu brzmi: Rozmowy telefoniczne przy pomocy budzika. A pierwsze zdanie odsyła właśnie do książki Caro, brzmi zaś następująco: „Czytając książki, poświęcone emigracji, bardzo często nie możemy wyjść z podziwu nad niezwykłym wprost rozwydrzeniem żydowskich hien emigracyjnych, obdzierających bez litości co do ostatnich groszy biednych emigrantów". Już bez antyżydowskiej retoryki opowieść cytować będą późniejsi autorzy, piszący u trudnych dziejach polskiej emigracji zarobkowej².

${ }^{1}$ L. Caro, Emigracja i polityka emigracyjna ze szczególnym uwzględnieniem stosunków polskich, tłum. z niemieckiego wydania książki autora, uzupełnił i znacznie rozszerzył K. Englisch, Poznań 1914, s. 84.

${ }^{2}$ Por. K. Wachtel [Wachtl], Polonia w Ameryce. Dzieje i dorobek, wstęp S. Zapała, Filadelfia 1944, s. 68; G.M. Kowalski, Przestępstwa emigracyjne w Galicji, 18981918. Z badań nad dziejami polskiego wychodźstwa, Kraków 2003, s. 199. 
„Gazeta Lwowska”, która szczegółowo na bieżąco relacjonowała proces, tak opisała oskarżonego Landerera: „mężczyzna w sile wieku, noszący się po angielsku, z zarostem przyprószonym siwizną, twarz ma bez wyrazu; na zapytania prokuratora odpowiada niepewnym i cichym głosem"3. Opis to, można powiedzieć, neutralny, stonowany, zwłaszcza gdy porównamy go z charakterystyką innego podejrzanego, Ukraińca Michała Rudawskiego:

Na głowie czupryna czarna, wygląda tak, jak gdyby kto skórę jeża na czarno ufarbował i włożył ją Rudawskiemu na głowę kolcami do góry i naciągnął tak silnie, że ta koląca czarna czupryna zachodzi mu na brwi prawie, tak że czoło jego pokryte sterczącym czarnym włosem. Twarz okrągła z rumieńcem, wąsy po tatarsku się zwieszające. Na grzbiecie ma wytartą brązową gunię, buty olbrzymie, ciężkie, tak że Rudawski potrzebuje chwilę czasu, by ten ciężar ze stopą posunąć naprzód ${ }^{4}$.

Wątek budzika opisuje „Gazeta Lwowska” w korespondencji z sali sądowej, z informacją „Wadowice, 15 listopada”, streszczając akt oskarżenia:

Przy sprzedaży kart okręgowych w kancelarii hamburskiej porozumiewano się 'telegraficznie' z Hamburgiem lub z Ameryką, i to na zwyczajnym budziku. Jeden ze spólników agencji, którego wychodźcom jako dyrektora okrętu przedstawiano, zapytywał, puszczając w ruch budzik, czy dla wychodźców jest miejsce na okręcie, po czym za chwilę ponownie budzik nastawiano i w ruch puszczano, a wtedy to nadchodziła odpowiedź, za którą wychodźcy również opłacać się musieli. Na owym budziku zapytywano również Amerykę, czy będzie grunt dla wychodźców, za co łatwowierni podobnież płacić musieli. Zapytywano wreszcie 'cesarza amerykańskiego', czy przyjmie wychodźców do Ameryki. Pomysł ten telegrafowania na budziku nie był nowością, bo spólnicy agencji hamburskiej, Landerer i Landau, już przed rokiem 1887, a więc w czasie kiedy w Podgórzu, Krakowie i Oświęcimiu na własną rękę ułatwianiem wychodźstwa pokątnie się trudnili, w ten sposób z Hamburgiem i Ameryką imieniem wychodźców się porozumiewali. Landerer używał budzika także na straszaka, bo gdy wychodźcy od niego kart okrętowych zakupić, lub tyle, ile za nie żądał,

${ }^{3}$ „Gazeta Lwowska”, 24 listopada 1889.

${ }^{4}$ „Gazeta Lwowska”, 3 grudnia 1889. 
zapłacić nie chcieli, straszył ich, że zatelegrafuje po żandarmów, aby ich zabrali, i w wykonaniu pogróżki budzik w ruch wprawiał ${ }^{5}$.

25 listopada budzik pojawił się fizycznie na sali sądowej. Zaraz po zakończeniu przesłuchania Landerera pytano buchaltera i korespondenta agencji, Hałatka („Ubrany bardzo zgrabnie, z pewną przesadą don Juana małomiasteczkowego, który ma wielkie powodzenie w całym miasteczku, i słynie z niego na okolicę. On to przyniósł budzik do agencji, ów słynny budzik, na którym telegrafowano do «cesarza amerykańskiego»"). Oto jego zeznanie:

Szybko przechodzi przewodniczący do sprawy budzika.

Przew [o dnic zą c y ] : A budzik kto przyniósł?

Hała te k: Ja. Kupiłem go w kwietniu albo maju 1888 r[oku] i był u mnie w pokoiku. Gdy się zepsuł, wziąłem go do kancelarii, by uregulować według zegaru kancelaryjnego. Nie wiem, czy go Gutman nakręcił, dość na tym, że gdy raz wychodźcy opuszczali kancelarię do pociągu południowego, budzik zaczął warczeć. Jeden z wychodźców rzekł wtedy, że to pewno telegraf, a Gutman skorzystał z tego i potwierdził. Herz, jak się dowiedział o tym, gniewał się ${ }^{6}$.

Ten wątek znika w późniejszej publicystyce. Nie pasowało do schematu ,żydowskich hien", żerujących na polskich wychodźcach to, że cały pomysł wziął się z ignorancji jednego z chłopów, obróconej w żart przez dowcipnego pracownika agencji, skarconego zresztą za to przez szefa.

$\mathrm{Na}$ rozprawie jeden ze świadków obciążał Landerera, twierdząc, że już wcześniej oszukiwał on za pomocą budzika. 15 I 1890 roku obrońca, dr Goldhammer, prosił o:

dopuszczenie kilkunastu świadków, których zeznania posłużyć mają do przedstawienia zeznań świadka Chaima Rettera we właściwym świetle. Retter przesłuchany tu przedstawił A[brahama] Landerera jako wynalazcę

${ }^{5}$ „Gazeta Lwowska”, 17 listopada 1889.

${ }^{6}$ „Gazeta Lwowska”, 27 listopada 1889. 
budzików, świadcząc jakoby on już przed kilku laty za pomocą budzika oszukiwał chłopów. Powołani świadkowie, którzy od kilkunastu lat razem z Landererem mieszkają potwierdzą, że Landerer nigdy nie miał budzika w swoim mieszkaniu?

12 III 1890 roku Abraham Landerer, z budzikiem czy bez, otrzymał w procesie wadowickim wyrok czterech i pół lat więzienia.

Akta procesu i koncept dzwonienia budzikiem do cesarza amerykańskiego posłużą austriackiemu pisarzowi Martinowi Pollackowi jako oś kompozycyjna książki Kaiser von Amerika. Die große Flucht aus Galizien.

Kiedy 16 marca 2011 roku podczas lipskich targów książki Martin Pollack odbierał nagrodę za działanie na rzecz europejskiego zrozumienia, pisarka Sibylle Lewitscharoff mówiła w laudacji o jego melancholii, o powikłanej historii rodzinnej i o sztuce pisania - głównie na przykładzie Cesarza Ameryki. Podkreśliła, że rzecz jest, ,świetnie udokumentowana i wybornie napisana”. Zwróciła uwagę na niesamowitość rodzących się skojarzeń z późniejszą o parę dziesięcioleci rzeczywistością obozów zagłady - np. w scenie zatrzymania pociągu z wychodźcami, wśród których stwierdzono cholerę, gdy upychano pasażerów w barakach i poddawano brutalnej dezynfekcji, albo kiedy, już na Ellis Island, haczykami do zapinania guzików odchylano emigrantom powieki, by zbadać, czy nie chorują na oczy, a oni myśleli, że chce im się oczy wyłupić. Najobszerniej wszakże zrelacjonowała historię z budzikiem-telegrafem ${ }^{8}$. Autorka laudacji, trzeba dodać, zna się na zegarach i zegarkach. Nie przypadkiem w jej powieści Consummatus występuje młody człowiek, który posiada kolekcję 669 zegarków - „od zegarka z Myszką Miki po zegar z kukułką"9.

7 „Gazeta Lwowska”, 18 stycznia 1890.

${ }^{8}$ Por.: http://www.boersenblatt.net/laudatio_auf_martin_pollack.432350.html [dostęp 19.08.15].

${ }^{9}$ S. Lewitscharoff, Consummatus, München 2006, s. 120. 
W książce Martina Pollacka rozdział opisujący akcję masowego aresztowania żydowskich pośredników, podejrzanych o wykorzystywanie nieświadomych wychodźców, zbudowany jest w myśl reguł narracji sensacyjnej, przy czym istotną rolę odgrywają kwestie łączności i komunikacji. W nocy z 22 na 23 lipca 1888 roku wadowicki nadprokurator Henryk Ogniewski rusza fiakrem do Oświęcimia. Dla zapewnienia pełnej tajemnicy nakazał pod pozorem szkód wyrządzonych przez burzę przerwać na tę noc połączenia telegraficzne między Krakowem, Wadowicami i Oświęcimiem. O tej samej godzinie (panowie przed akcją zsynchronizowali zegarki) wyrusza z Krakowa komisarz policji Władysław Swolkień z protokolantem i dziesięcioma doborowymi policjantami. Podwładni policjanta dopiero tuż przed Oświęcimiem dowiadują się o istotnym celu akcji. Punktualnie o czwartej rano przedstawiciele prawa wkraczają do hotelu „de Zator”, w którym działał Szymon Herz oraz do innych budynków. Okazuje się, że pomiędzy luksusową willą Herza, wyposażoną w system dzwonków między poszczególnymi pomieszczeniami, a hotelem-siedzibą agencji była specjalna linia telefoniczna - akcję przeprowadzono jednak tak sprawnie, że ani główny podejrzany nie zdążył zadzwonić, ani nikt go nie ostrzegł.

Wątek telegrafowania za pomocą budzika pojawia się niemal idealnie w środku książki. Jako wyjaśnienie, jak możliwe było tak grubymi nićmi szyte oszustwo, Pollack przytacza zeznania rusińskiego chłopa małorolnego Mykołaja Malyniaka z Grybowa w Beskidach, który zeznał przed sądem, że nigdy przedtem nie widział zegarka. Od siebie autor dodaje, że w wielu galicyjskich wsiach nikt wtedy nie ma zegarka - chłopi orientowali się w czasie podług słońca, gwiazd albo piania kogutów ${ }^{10}$.

Mykołaj Malyniak pojawia się dalej w książce, gdy mowa o jego trudnej do zrozumienia mowie:

${ }^{10}$ Por. M. Pollack, Kaiser von Amerika. Die große Flucht aus Galizien, Wien 2010, s. 134. 
Mykołaj Malyniak, ten sam, który zegarek pierwszy raz w życiu zobaczył w agencji Herza, bełkocze coś w trudnym do zrozumienia ukraińskim dialekcie, sąd i słuchacze mogą z tego potoku słów wyłowić tylko dziandar, co ma chyba oznaczać żandarma, oraz stale powtarzające się głośne hej, hej!, którymi Malyniak kończy każde zdanie ${ }^{11}$.

Ale przecież cała książka Pollacka zaczyna się od opisu zatrzymania w galicyjskiej wsi Stare Sowy kilku wychodźców słowackich z osady Brutovce na Spiszu i od dalszej podróży przez Hamburg do Nowego Jorku ośmiu w sumie kompanów z tej wsi, z których jeden to „Mihály Malinyak, [lat] 33”12. W tej sytuacji trudno się dziwić, że obdarzona wyczulonym na fałsz uchem krytycznym Paulina Małochleb napisała na swym blogu Książki na ostro:

Nie ma tu miejsc pustych, niejasności, mało urwanych historii o pojedynczych osobach. I dlatego właśnie nie wierzę w tę opowieść - bo jest zbyt gładka, bo daje odpowiedzi na wszystkie pytania, a to po prostu niemożliwe. [...] Pollack jest pewnego rodzaju hochsztaplerem, który ukrywa ściegi swojej historii ${ }^{13}$.

W dniu ukazania się polskiego wydania książki Pollacka, 2 IX 2011 roku, program III Polskiego Radia, który nadał publikacji „Trójkowy Znak Jakości”, emitował rozmowę Wojciecha Manna z Michałem Nogasiem. Internetowej wersji tej rozmowy towarzyszy artykuł Nogasia Budzik do kontaktów z Cesarzem..., na nowo relacjonujący trick Landerera:

Jest w Cesarzu Ameryki scena niezwykła. Rozgrywa się w Hamburgu, porcie, z którego wielkie statki odpływają do Nowego Świata. By się do

${ }^{11}$ M. Pollack, Cesarz Ameryki. Wielka ucieczka z Galicji, tłum. K. Niedenthal, Wołowiec 2011; por. M. Pollack, Kaiser..., s. 169.

${ }^{12}$ M. Pollack, Kaiser..., s. 15.

${ }^{13}$ P. Małochleb, http://krytykanaostro.blogspot.ch/2012/09/mieso-historii.html [data dostępu: 21.08.15] 
tego świata dostać, biedni galicyjscy chłopi muszą kupić bilety. Na podróż między pokładami. Jeden $\mathrm{z}$ agentów wielkiego armatora negocjuje z nimi warunki transakcji przy pomocy blaszanego budzika. Nakręca go, a gdy urządzenie dzwoni, udaje, że właśnie otrzymał telegram. Swemu wyimaginowanemu rozmówcy za wielką wodą zadaje kolejne pytania - najpierw o miejsce na statku, potem o to, czy dla nowo przybyłych znajdzie się kawałek ziemi. Wreszcie łączy się z samym, również wymyślonym, cesarzem Ameryki. Łaskawie pyta go, czy będzie w stanie zaopiekować się nowymi poddanymi? Odpowiedź na każde pytanie jest pozytywna. Biedacy mogą płynąć. Ale zabawa w telegraf kosztuje każdego z - i tak nie mających już prawie nic - chłopów kolejne kilkadziesiąt guldenów. Agent wręcza im bilet i rozpoczyna 'zabawę' $\mathrm{z}$ kolejnymi klientami ${ }^{14}$.

Na podstawie książki Pollacka Robert Urbański napisał sztukę Cesarz Ameryki, wystawioną przez Teatr Polski w Bielsku Białej (premiera 20 IV 2013). W spektaklu jedna $\mathrm{z}$ kluczowych scen to pełne napięcia zbiorowe oczekiwanie kandydatów do emigracji na rozmowę telefoniczną przez budzik.

W tym samym roku 1890, kiedy skończył się proces wadowicki, w Anglii i w Ameryce ukazała się powieść utopijna Edwarda Bellamy’ego Looking Backward. „Gazeta Lwowska” w kilku kolejnych numerach publikowała streszczenie tej nowości. W jednym $\mathrm{z}$ odcinków pojawia się informacja o wynalazku zmodyfikowanego budzika. Bohater powieści, Julian West, który zasnął 30 V 1887 roku, a obudził się w 10 IX 2000 roku, ,dzięki wydoskonalonemu ulepszeniu budzika zapewnia sobie przyjemność zostania zbudzonym odgłosem Marsza tureckiego, który przenosi jego sny do samej Alhambry, na tron Abenceragów"15.

Proroctwo Bellamy'ego o budzeniu muzyką z telefonu sprawdzi się niemal co do joty w postaci mody na umieszczanie ulubionych melodii $\mathrm{w}$ telefonach

${ }^{14}$ M.Nogaś, Budzikdokontaktówz Cesarzem...http://www.polskieradio.pl/24/112/ Artykul/430455,Budzik-do-kontaktow-z-Cesarzem [data dostępu: 19.08.15].

${ }^{15}$ „Gazeta Lwowska”, 18 grudnia 1890. 
komórkowych, używanych także jako budziki (trzecia generacja telefonii komórkowej to rok 2001).

W ten sposób spotykają się w czasie dwie narracje o połączeniu budzika z telefonem. $\mathrm{W}$ jednej jest ono znakiem zacofania, w drugiej symbolem postępu. 


\section{Chronometer. A Talkative Alarm Clock}

The paper discusses several cases of using and abusing an authentic incident from the history of emigration from Galicia to the United States at the end of the XIX century, when a Jewish agent was cheating illiterate peasants who had never seen a clock before, pretending he was communicating with Hamburg and New York through a simple alarm-clock. The examples are drawn from the daily press of that time, various newspapers in the twenties and thirties, several books dealing with the subject of emigration as well as Martin Pollack's Kaiser von America (2010) and its stage adaptation in Bielsko-Biała (2013). Edward Bellamy's utopia Looking Backward is given as a counter-example, with its vision of an alarm-clock used as a source of pleasant music around the year 2000 - a vision realised in our world almost at the same time with a new generation of mobile phones.

Keywords: emigration, abuses, alarm-clock as a phone, Martin Pollack, Edward Bellamy, mobile phones. 


\section{Nowości Wydawnictwa UKSW}

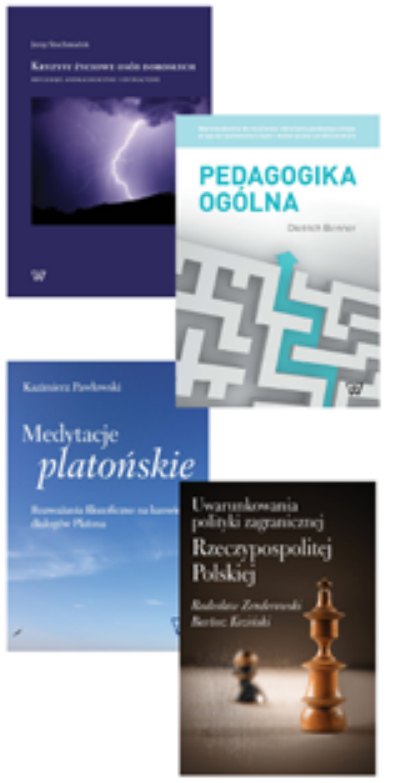

- Jerzy Stochmiałek, Kryzysy życiowe osób dorosłych

- Dietrich Benner, Pedagogika ogólna

- Kazimierz Pawłowski, Medytacje platońskie. Rozważania filozoficzne na kanwie dialogów Platona

- Bartosz Koziński, Radosław Zenderowski, Uwarunkowania polityki zagranicznej Rzeczypospolitej Polskiej

Więcej informacji na stronie: www.wydawnictwo.uksw.edu.pl 